Республики Таджикистан. Душанбе -2020. С. 325 331.

10.М.Б. Акрамов. Влияния металлических примесей на теплофизические свойства Al. X international correspondence scientific specialized conference «International scientific review of the problems of natural sciences and medicine» (Boston. USA. April 2-3, 2019) PP. 16-26.

11.М.Б. Акрамов, Ф. Мирзоев, 3 Низомов. Применение современных технологий и инновационных методов исследования в научноисследовательских работах. Вестник кыргызского экономического университета имени М.Рыскулбекова 2 (29) 2014 г. Бишкек -2014 с 5053.

12.М.Б. Акрамов. Температурная зависимость теплофизических свойств алюминия марки А 5. Доклады АН Р Таджикистан. 2014 г. №2, том 57. С 140-144.

\title{
SWARM INTELLIGENCE
}

DOI: 10.31618/ESU.2413-9335.2020.6.77.998

${ }^{I}$ G.B. Issayeva, ${ }^{1}$ M.S. Ibraev , ${ }^{2}$ A.K. Koishybekova, ${ }^{3}$ B.R. Absatarova, ${ }^{1}$ A.A. Aitkazina, ${ }^{1}$ Sh.P.

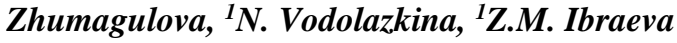

https://orcid.org/0000-0002-4860-3797

${ }^{1}$ AUPET University, Almaty

${ }^{2}$ Zhetysu State University named by I. Zhansugurov, Taldykorgan

${ }^{3}$ KazRDICE University, Almaty

\author{
АҚЫЛДЫ ИНТЕЛЛЕКТ \\ ${ }^{1}$ Г.Б. Исаева, ${ }^{1}$ М.С. Ибраев, ${ }^{2}$ А.К. Қойшыбекова, ${ }^{3}$ Б.Р. Абсатарова, ${ }^{1}$ А.А. Айтқазина, ${ }^{1}$ Ш.П. \\ Жұмагұлова, ${ }^{1}$ Н. Водолазкина, ${ }^{1}$ З.М. Ибраева \\ ${ }^{I}$ АЭжБУ университеті, Алматы \\ ${ }^{2}$ Жансүгіров атындавы Жетісу мемлекеттік университеті, Талдықорван \\ ${ }^{3}$ ҚазҚСҒЗИ университеті, Алмать
}

\section{ИНТЕЛЛЕКТ РОЯ}

\author{
${ }^{1}$ Г.Б. Исаева, ${ }^{1}$ М.С. Ибраев, ${ }^{2}$ А.К. Қойшыбекова, ${ }^{3}$ Б.Р. Абсатарова, ${ }^{1}$ А.А. Айтқазина, ${ }^{1}$ ШШ.П. \\ Жұмагұлова, ${ }^{1}$ Н. Водолазкина, ${ }^{1}$ З.М. Ибраева \\ ${ }^{1}$ Университет АУЭС, Алматьи \\ ${ }^{2}$ Жетисуский Государственный Университет имени И. Жансигурова, Талдыкорган \\ ${ }^{3}$ Университет КазНИИСА, Алматьь
}

\section{ANNOTATION}

This report investigates this discipline that deals with natural and artificial systems. In the past few years there has been a lot of research on the application of swarm intelligence. A large number of algorithms have been used in different spheres of our life. In this paper we give an overview of this research area. We identify one of the algorithms of swarm intelligence systems and we show how it is used to solve problems. In other words, we present Bee Algorithms, a general framework in which most swarm intelligence algorithms can be placed. After that, we give an extensive solution of existing problem, discussing algorithm's advantages and disadvantages. We conclude with an overview of future research directions that we consider important for the further development of this field.

\section{АННОТАЦИЯ}

Бұл есеп табиғи және жасанды жүйелерге қатысты осы пәнді зерттейді. Соңғы бірнеше жыл ішінде интеллектті қолдану бойынша көптеген зерттеулер жүргізілді. Көптеген алгоритмдер біздің өміріміздің әртүрлі салаларында қолданылды. Осы жұмыста біз осы зерттеу саласына шолу жасаймыз. Біз қаруланған интеллект жүйелерінің алгоритмдерінің бірін анықтаймыз және оның есептерді шығару үшін қалай қолданылатындығын көрсетеміз. Басқаша айтқанда, біз назарларыңызға алгоритмдердің көпшілігін орналастыруға болатын жалпы шеңбер Вее алгоритмдерін ұсынамыз. Осыдан кейін біз алгоритмнің артықшылықтары мен кемшіліктерін талқылай отырып, бар мәселенің кең шешімін табамыз. Біз осы саланы одан әрі дамыту үшін маңызды деп санайтын болашақ зерттеу бағыттарын шолумен аяқтаймыз.

\section{АННОТАЦИЯ}

Этот отчет исследует эту дисциплину, которая имеет дело с естественными и искусственными системами. В последние несколько лет было проведено много исследований по применению разведки роя. Большое количество алгоритмов было использовано в разных сферах нашей жизни. В этой статье мы даем обзор этой области исследований. Мы определяем один из алгоритмов систем разведки роя и показываем, как он используется для решения проблем. Другими словами, мы представляем Bee Algorithms, общую структуру, в которую можно поместить большинство алгоритмов разведки роя. После этого мы подробно рассмотрим существующую проблему, обсудим достоинства и недостатки алгоритма. Мы завершаем обзор будущих направлений исследований, которые мы считаем важными для дальнейшего развития этой области. 
Key words: swarm, contact, intelligence, source, natural, artificial, system, algorithm, research area, investigation, problem, solution, etc.

Түйінді сөздер: сілкініс, байланыс, ақыл, дереккөз, табиғи, жасанды, жүйе, алгоритм, зерттеу аймағы, тергеу, мәселе, шешім және т.б.

Ключевые слова: рой, контакт, интеллект, источник, естественное, искусственное, система, алгоритм, область исследования, исследование, проблема, решение и т.д.

A swarm is a large number of homogenous, simple agents interacting locally among themselves, and their environment, with no central control to allow a global interesting behavior to emerge. Swarm-based algorithms have recently emerged as a family of natureinspired, population-based algorithms that are capable of producing low cost, fast, and robust solutions to several complex problems. Swarm Intelligence (SI) can therefore be defined as a relatively new branch of Artificial Intelligence that is used to model the collective behavior of social swarms in nature, such as ant colonies, honey bees, and bird flocks. Although these agents (insects or swarm individuals) are relatively unsophisticated with limited capabilities on their own, they are interacting together with certain behavioral patterns to cooperatively achieve tasks necessary for their survival. The social interactions among swarm individuals can be either direct or indirect. Examples of direct interaction are through visual or audio contact, such as the waggle dance of honey bees. Indirect interaction occurs when one individual changes the environment and the other individuals respond to the new environment, such as the pheromone trails of ants that they deposit on their way to search for food sources. More specifically, this paper discusses one of the most popular models of swarm intelligence inspired by bees' behavior.

In the past decades, biologists and natural scientists have been studying the behaviors of social insects because of the amazing efficiency of these natural swarm systems. In the late-80s, computer scientists proposed the scientific insights of these natural swarm systems to the field of Artificial Intelligence. In 1989, the expression "Swarm Intelligence" was first introduced by G. Beni and J. Wang in the global optimization framework as a set of algorithms for controlling robotic swarm. In 2005, Artificial Bee Colony Algorithm was proposed by D. Karabago as a new member of the family of swarm intelligence algorithms.

Since the computational modeling of swarms was proposed, there has been a steady increase in the number of research papers reporting the successful application of Swarm Intelligence algorithm in several optimization tasks and research problems.
The remainder of this paper is organized as follows: The next section presents an overview of natural swarm system (Bees). Then, the last section summarizes the advantages and limitations of swarm intelligence and provides some concluding remarks on the paper and open questions of the field.

Swarm intelligence is the discipline that deals with natural and artificial systems composed of many individuals that coordinate using decentralized control and self-organization. In particular, the discipline focuses on the collective behaviors that result from the local interactions of the individuals with each other and with their environment. Swarm intelligence models are referred to as computational models inspired by natural swarm systems. To date, several swarm intelligence models based on different natural swarm systems have been proposed in the literature, and successfully applied in many real-life applications. Examples of swarm intelligence models are: Ant Colony Optimization, Particle Swarm Optimization, Artificial Bee Colony, Bacterial Foraging, Cat Swarm Optimization, Artificial Immune System, and Glowworm Swarm Optimization. In this paper, we will primarily focus on one of the most popular swarm intelligences models, namely, Bee Colony.

The Bees Algorithm is inspired by the foraging behavior of honey bees. Honey bees collect nectar from vast areas around their hive (more than 10 kilometers). Bee Colonies have been observed to send bees to collect nectar from flower patches relative to the amount of food available at each patch. Bees communicate with each other at the hive via a waggle dance that informs other bees in the hive as to the direction, distance, and quality rating of food sources. The information processing objective of the algorithm is to locate and explore good sites within a problem search space. Scouts are sent out to randomly sample the problem space and locate good sites. The good sites are exploited via the application of a local search, where a small number of good sites are explored more than the others. Good sites are continually exploited, although many scouts are sent out each iteration always in search of additional good sites, the process is repeated. 


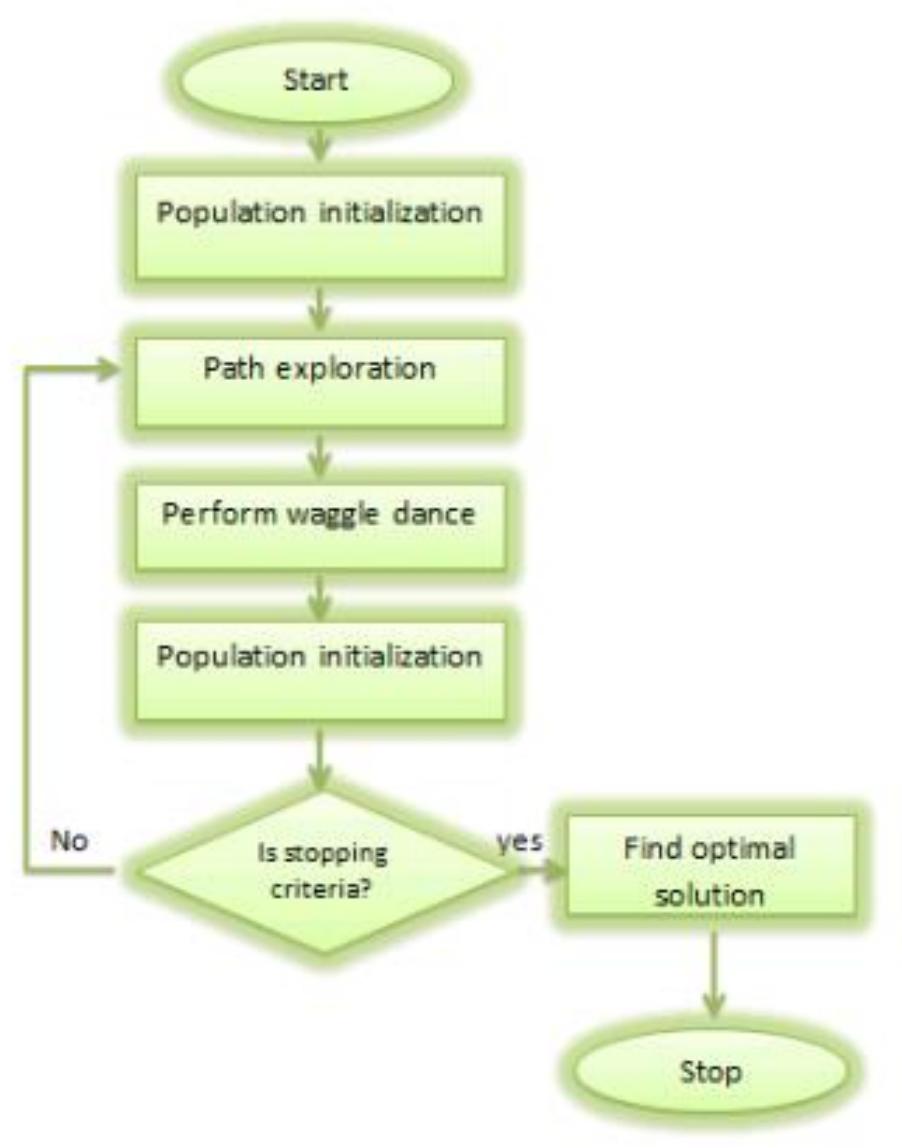

Process Bee colony algorithm

Step 1: Assign control parameters

Step 2: Initialize solutions

Step 3: Repeat until stopping criteria is met

$\square$ Send the employed bee and calculate fitness

Send the onlookers and calculate fitness

Send the scout bees

Memorize the best solution

Step 4: Stop condition

Using Bee algorithm we can find a global maximum of function.

Let consider one function $f(x, y)=-\left(x^{\wedge} 2+y^{\wedge} 2\right)$.

The sign "_" is placed because of the function has a global maximum, not minimum. Global and single maximum of this function is in the point $(0 ; 0)$, where $\mathrm{f}(0,0)=0$.

Necessary parameters:

The number of bees scouts: 10 5

The number of bees that are sent to the best sites: areas: 2

The number of bees that are sent to other selected

The number of the best sites: 2

The number of selected areas: 3

The size of each section: 10

Let the scouts were the following, portions (list sorted in descending order of the objective function):

$\mathrm{f}(15,18)=-549$

$\mathrm{f}(-30,-15)=-1125$

$f(22,-31)=-1445$

$\mathrm{f}(18,40)=-1924$

$f(-25,47)=-2834$ $\mathrm{f}(60,86)=-10996$

$\mathrm{f}(-91,-99)=-18082$

$f(17,-136)=-18785$

$\mathrm{f}(-152,-1)=-22501$

$f(-222,157)=-73933$

First, the best points will be chosen:

$f(15,18)=-549$

$\mathrm{f}(-30,-15)=-1125$

Then, other 3 points of the perspective areas will be chosen:

$f(22,-31)=-1445$

$\mathrm{f}(18,40)=-1924$

$\mathrm{f}(-25,47)=-2834$

In the neighborhood of the best points will be sent by 5 bees:

For the first best point coordinate value, which is limited to the site will be:

$[15-10=5 ; 15+10=25]$ for the first coordinate

$[18-10=8 ; 18+10=28]$ for the second coordinate

And for the second point:

$[-30-10=-40 ;-30+10=-20]$ for the first coordinate

$[-15-10=-25 ;-15+10=-5]$ To the second position

Similarly, the intervals are calculated for selected areas:

$[12 ; 32][-41 ;-21]$

$[8 ; 28][30 ; 50]$

$[-35 ; 15][37 ; 57]$

Note that here for each of the coordinates the size of the area is 20 , but in reality it is not necessarily so. 
In each of the top five points we sent our bees. And also to selected areas on two bees. And, we will not change the position of the bees who have found the best and selected areas, otherwise there is the likelihood that the next iteration of the maximum value of the objective function will be worse than in the previous step.

Now suppose that in the first section, we have the best following bees:

$f(15,18)=-549$

$\mathrm{f}(7,12)=193$

$\mathrm{f}(10,10)=100$

$\mathrm{f}(16,24)=832$

$\mathrm{f}(18,24)=900$

As you can see, among these new points, there are some that are better than the previous solution.

So the same actions with the second section, and then similarly with the selected area. Then among all the new points again, marked the best candidates, and the process repeats.

Here you need to pay attention to one feature that may be important in the implementation of the algorithm. A few bees can get to the same area (close to each other, the size of the area, or perhaps the proximity of bees given a separate option). Therefore, there are two variants of behavior:

We believe that these two bees found two different intersecting sections and both of these areas noted as the best or selected.

Also, there is one area whose center is at the point that corresponds to a bee with a large value of the objective function.

In the implementation of which will be described below, a second variant of behavior, as it seemed less prone to jamming in local extremes.

This algorithm is introduced in the real life.

Let consider one example. Assume that there is an accident which connected with a shipwreck. As a consequence, there are lots of people who are in the water. Using the above-mentioned method, we implement such drones instead our bees. These drones randomly direct in order to know the places with the most number of people and send the information to the base. With the received data the rescuers are send firstly to these places most number of people of people. Secondly, to the places with less number of people and so on.

\section{Summary}

In conclusion, it can be stated that the swarm intelligence can be used in the number of applications. As we mentioned before, we used bee algorithm in our real life to solve problems and make human life easy. Such as unmanned aerial vehicles (considered in application). Using this information, we will make a program, which shows the possibilities of the bees algorithm.

\section{Literature:}

1. I. F. Akyildiz, X. Wang, and W. Wang. Wireless mesh networks: a survey. Computer Networks Journal, 47(4):445-487, 2005.

2. I. F. Akyildiz, S. Weilian, Y. Sankarasubramaniam, and E. Cayirci. A survey on sensor networks. IEEE Communications Magazine, 40(8):102-116, 2002.

3. R. Asokan, A. Natarajan, and A. Nivetha. A swarm-based distance vector routing to support multiple quality of service metrics in mobile ad hoc networks. Journal of Computer Science, 3(9):700-707, 2007.

4. O. Babaoglu, G. Canright, A. Deutsch, G.A. Di Caro, F. Ducatelle, L.M. Gambardella, N. Ganguly, M. Jelasity, R. Montemanni, A. Montresor, and T. Urnes. Design patterns from biology for distributed computing. ACM Transactions on Autonomous and Adaptive Systems (TAAS), 1(1):26-66, 2006.

5. B. Baran and R. Sosa. A new approach for AntNet routing. In Proceedings of the 9th International Conference on Computer Communications and Networks (ICCCN), pages 303-308, Washington, DC, 2000. IEEE Computer Society.

6. J. S. Baras and H. Mehta. A probabilistic emergent routing algorithm for mobile ad hoc networks. WiOpt03: Modeling and Optimization in Mobile, Ad Hoc and Wireless Networks, 2003.

7. R. Bellman. Dynamic Programming. Princeton University Press, Princeton, NJ, 1957.

8. R. Bellman. On a routing problem. Quarterly of Applied Mathematics, 16(1):87-90, 1958.

9. L. Blazevic, L. Buttyan, S. Capkun, S. Giordano, J.-P. Hubaux, and J.-Y. Le Boudec. Selforganization in mobile ad-hoc networks: the approach of terminodes. IEEE Communications Magazine, 39(6), 2001.

10. E. Bonabeau, M. Dorigo, and G. Theraulaz. Swarm Intelligence: From Natural to Artificial Systems. Oxford University Press, New York, NY, 1999.

11. E. Bonabeau, F. Henaux, S. Gu'erin, D. Snyers, P. Kuntz, and G. Theraulaz. Routing in telecommunication networks with "smart" ant-like agents. In Proceedings of IATA'98, Second Int. Workshop on Intelligent Agents for Telecommunication Applications, volume 1437 of Lecture Notes in Artificial Intelligence, pages 60-71, Berlin, Germany, 1998. Springer.

12. J.A. Boyan and M.L. Littman. Packet routing in dynamically changing networks: a reinforcement learning approach. In Advances in Neural Information Processing Systems 6 (NIPS6), pages 671-678, San Francisco, CA, 1994. Morgan Kaufmann.

13. R. Braden, D. Clark, and S. Shenker. Integrated services in the internet architecture: an overview. RFC 1633 (Informational), 1994.

14. J. Broch, D. A. Maltz, D. B. Johnson, Y.-C. $\mathrm{Hu}$, and J. Jetcheva. A performance comparison of multi-hop wireless ad hoc network routing protocols. In Proceedings of the Fourth Annual ACM/IEEE International Conference on Mobile Computing and Networking (MobiCom), pages 85-97, New York, NY, 1998. ACM.

15. D. C`amara and A.A.F. Loureiro. GPS/ANTlike routing in ad hoc networks. Telecommunication Systems, 18(1-3):85-100, 2001.

16. T. Camilo, C. Carreto, J. S'a Silva, and F. Boavida. An energy-efficient ant-based routing 
algorithm for wireless sensor networks. In Proceedings Swarm intelligence for routing in telecommunications networks 27 of the 5th International Workshop on Ant Colony Optimization and Swarm Intelligence (ANTS), volume 4150 of Lecture Notes in Computer Science, pages 49-59, Berlin, Germany, 2006. Springer.

17. G. Canright. Ants and loops. In Proceedings of the 3rd International Workshop on Ant Algorithms (ANTS), volume 2463 of Lecture Notes in Computer Science, pages 235-242, Berlin, Germany, 2002. Springer.

18. L. Carrillo, C. Guadall, J. L. Marzo, G. Di Caro, F. Ducatelle, and L. M. Gambardella. Differentiated quality of service scheme based on the use of multi-classes of ant-like mobile agents. In CoNEXT'05: Proceedings of the 2005 ACM conference on Emerging network experiment and technology, pages 234-235, New York, NY, 2005. ACM.

19. L. Carrillo, J.L. Marzo, D. Harle, and P. Vil`a. A review of scalability and its application in the evaluation of the scalability measure of AntNet routing. In Proceedings of the IASTED Conference on Communication Systems and Networks (CSN), pages 317-323, Calgary, Canada, 2003. ACTA Press.

20. N. Cauvery and K. Viswanatha. Enhanced ant colony based algorithm for routing in mobile ad hoc network. Proceedings of World Academy of Science, Engineering and Technology, 36:30-35, 2008.

21. I. D. Chakeres and C. E. Perkins. Dynamic MANET on-demand routing protocol. Internet Draft,

УДК 622.271

ГРНТИ 52.45.93
2008.

Information about authors:

Issayeva G., Candidate of Pedagogical Sciences, AUPET University, Almaty city,

Ibraev M., Candidate of Technical Sciences, AUPET University, Almaty city

Koishybekova A., Master of Technical Sciences, Zhetysu State University named by I. Zhansugurov, Taldykorgan

Absatarova B., Master of Technical Sciences, AUPET University, Almaty city

Aitkazina A., Master of Technical Sciences, AUPET University, Almaty city

Zhumagulova Sh., Master of Technical Sciences, AUPET University, Almaty city

Vodolazkina N., Master of Technical Sciences, AUPET University, Almaty city

Ibraeva Z., Master of Technical Sciences, AUPET University, Almaty city

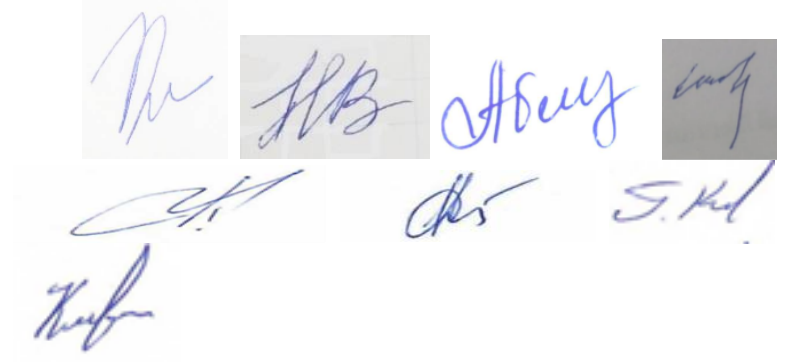

\section{СТРУКТУРНЫЕ СВЯЗИ И ВЗАИМОЗАМЕНЯЕМОСТЬ АССИМЕТРИЧНЫХ ТИПОВ} ТЕОРЕТИЧЕСКИХ РАСПРЕДЕЛЕНИЙ

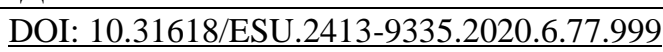

Курманкожаев Азимхан

Доктор технических наук, профессор,

Казахский наџиональный исследовательский технический университет,

Казахстан, г.Алмать

Есбергенова Эльмира Сейлбековна

Магистр технических наук,

Казахский наџиональный исследовательский технический университет,

UDC 622.271

Казахстан, г. Алмать

State rubricator of scientific and technical information 52.45.93

\section{STRUCTURAL CONNECTIONS AND INTERCHANGEABILITY OF ASYMMETRIC TYPES OF THEORETICAL DISTRIBUTIONS}

Kurmankozhayev Azimkhan

Doctor of technical sciences, professor, Kazakh national research technical university,

Kazakhstan, Almaty city

Yesbergenova Elmira Seilbekovna

Master of technical sciences,

Kazakh national research technical university,

Kazakhstan, Almaty city, 